\title{
Tanı Karmaşasına Yol Açan İki Olgu: Rett Sendromu
}

\author{
Two Cases Leading To Diagnostic Confusion:Rett Syndrome
}

\author{
Hilal Aydın', İbrahim Hakan Bucak², Haydar Bağış ${ }^{3}$ \\ ${ }^{1}$ Balıkesir Üniversitesi Tip Fakültesi Çocuk Sağlığı ve Hastalıkları Anabilim Dalı, Çocuk Nöroloji Bölümü, Balıkesir, Türkiye \\ ${ }^{2}$ Adıyaman Üniversitesi Tip Fakültesi, Çocuk Sağlığı ve Hastalıkları Anabilim Dalı, Adıyaman, Türkiye \\ ${ }^{3}$ Adıyaman Üniversitesi Tip Fakültesi, Tibbi Genetik Anabilim Dalı, 02200, Adıyaman, Türkiye. \\ Yazışma Adresi / Correspondence: \\ Hilal Aydın \\ Balıkesir Üniversitesi Tıp Fakültesi Çocuk Sağlığı ve Hastalıkları Anabilim Dalı, Çocuk Nöroloji Bölümü10145, Balıkesir

\begin{abstract}
T: + 902666121010 / 204381 E-mail: drhilalaydin@gmail.com
Orcid:

Hilal Aydın https://orcid.org/0000-0002-2448-1270

İbrahim Hakan Bucak https://orcid.org/0000-0002-3074-6327

Haydar Bağıș https://orcid.org/0000-0002-1140-8058
\end{abstract} \\ Geliş Tarihi / Received : 10.08.2019 Kabul Tarihi / Accepted : 10.01.2020 \\ ( Sakarya Tip Dergisi / Sakarya Med J 2020, 10(1):128-132 ) DOI: 10.31832/smj.604977 \\ Çalışma sözlü sunum olarak Adıyaman 6. Bilim, Kültür ve Sanat Sempozyumunda sunulmuștur.
}

$\ddot{\mathrm{O} z}$

Rett Sendromu (RS), normal gelișim basamaklarını takiben erken nörolojik regresyon ile tanınan ve kızlarda görülen nörogelișimsel bir hastalıktır. Klasik RS tanısı için; doğum öncesi, doğum sırası, doğum sonrası dönemleri ile ilk altı aya kadar gelişimin normal olması, doğumda baș çevresinin normal olup beș ay-dört yaş arasında azalması, edinilmiş amaca yönelik el becerilerinin kaybı (6-30 aylar arasında), alıcı ve ifade edici dilde ağır bozulma, ciddi psikomotor gerilik, stereotipik el hareketleri (burma, sıkma, ağıza götürme), apraksi, ataksi tanı için gerekli kriterlerdir. Rett Sendromunda mental-motor geriliğin yeni bașladığı dönemde yada gerilik öyküsünün net alınamadığı hastalarda tanı gecikebilir. Bu yazımızda çeşitli merkezlerde uzun süreli takiplerinde hipoksik iskemik ensefalopati ve nöromotor retardasyon tanıları izlenen ve kliniğimizde Rett Sendromu tanısı alan iki olgumuz sunuldu.

Anahtar Rett Sendromu; epilepsi; çocuk

kelimeler

Abstract

Rett syndrome (RS) is a neurodevelopmental disease seen in girls and diagnosed with early neurological regression following normal developmental stages. Diagnosis of classic RS requires findings of normal development in the pre, peri-and postnatal periods and in the first six months, normal head circumference at birth decreasing between the ages of five months and four years, loss of purposeful hand use (between 6 and 30 months), impairment of receptive and expressive language, severe psychomotor retardation, manual stereotypies (such as twisting, clenching, and mouthing), apraxia and ataxia. Diagnosis may be delayed in RS in patients with new onset mental-motor retardation or in whom no clear history of retardation can be obtained. Herein we report two cases diagnosed as Rett Syndrome in our clinics that was previously monitored in several centers and pre-diagnosed for neuromotor retardation, hypoxic ischemic encephalopathy 


\section{GIIRIŞ}

Rett Sendromu, normal gelişim basamaklarını takiben erken nörolojik regresyon ile tanınan ve kızlarda görülen nörogelişimsel bir hastalıktır. Rett Sendromu (RS) özellikle mikrosefali, kognitif yıkım, alıcı/ifade edici dil yeteneği ve amaçlı el hareketlerinin kaybı ile gider. ${ }^{1}$ Rett Sendromu, tüm toplumlarda benzer sıklıkta ve yaklaşık 15.00020.000 canlı kız doğumda bir görülmektedir. ${ }^{2}$ Hastalığın kendine özgü gidişi sayesinde Rett Sendromu tanısı klinik olarak konulur. Rett Sendromlu hastalar genellikle sorunsuz bir gebelik sonrasında zamanında doğar. Hastalarda çoğunlukla 12-18 aydan sonra konuşma yetisi ve amaçlı el hareketleri kaybedilir, stereotipik el hareketleri, duruş anormallikleri ve epileptik nöbetler ortaya çıkmaya başlar. $\mathrm{Bu}$ çalışmada çeşitli merkezlerde nöromotor regresyon tanıları ile izlenen ve epileptik nöbet geçirme nedeni ile çocuk nöroloji polkliniğine başvuran ve takiplerinde Rett Sendromu tanısı konulan 2 vakayı sunmayı hedefledik.

\section{Olgu 1}

6 yaşında kız hasta, dış merkezde nöromotor regresyon ve epilepsi tanısı ile izlemdeyken 2 dakika süren jeneralize tonik klonik nöbet geçirme şikayeti ile acil servisten ileri tetkik ve tedavi amacıyla servisimize yatırıldı. Hastanın prenatal, natal ve postanatal öyküsünde bir özellik yoktu. Anne-baba arasında akrabalık olmadığı ve amca çocuğunda nöbet geçirme öyküsü mevcut olduğu öğrenildi. Başını dik tutmaya 1.5 yaşında, destekli oturmaya 2 yaşında, desteksiz oturmaya 2.5 yaşında başladığı öğrenildi. Stereotipik hareketlerinin ise 2.5 yaşında ortaya çıktığı belirtildi. Diş merkezde epilepsi, nöromotor retardasyon nedeni ile klinik olarak izlemde olduğu, valproik asit ve klonazepam kullandığı öğrenildi. Olgunun fizik muayanesinde genel durumu orta, konuşamıyor, göz teması kısıtlı, baş çevresi: 46 cm (<-2 SD) idi. Kaba yüz görünümü, sterotipik el hareketleri, alt ekstremitede kısmi kontraktur, kifoskolyozu mevcuttu. Derin tendon refleksleri canlı, kendi başına desteksiz kısmi oturabiliyor ve diğer sistem muayaneleri doğaldı. Rutin laboratuvar tetkikleri normaldi. Jeneralize tonik klonik nöbet geçirmesi nedeni ile çekilen elektro- ensefalografisinde (EEG); çoğu zaman sol frontosantrotemporal bölgede zaman zaman sağ frontosantrotemporal bölgede dominans multifokal 3-4 Hz, diken/diken dalga deşarjlarının trasenin sonlarına doğru ısrarlı olarak devam ettiği saptandı (Resim 1).

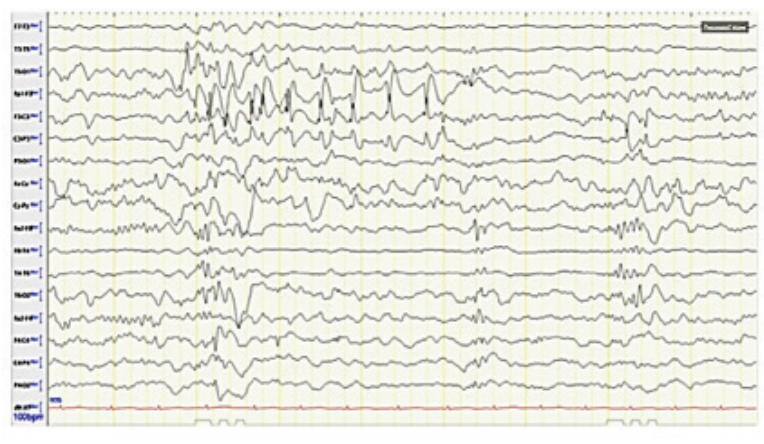

Resim 1. Elektroensefalografide çoğu zaman sol frontosantrotemporal bölgede dominans zaman zaman săg frontosantrotemporal bölgede dominans multifokal 3-4 Hz, diken/ diken dalga deşarjları

Kranial görüntülemesinde kortikal atrofi izlendi (Resim 2).

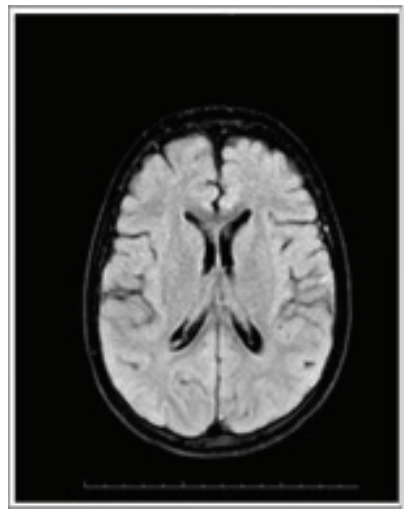

Resim 2. Kranial görüntülemede fluid attenuated inversion recovery (FLAIR) kesitlerde kortikal atrofi

Antiepilepitik ilaçları revize edilen hasta Rett Sendromu düşünülerek genetik bölümüne konsulte edildi. Genetik analizde metil-CpG bağlayıcı protein 2 (MECP2) genine ait sekans analizinde heterozigot C397C $>$ T mutasyonu izlendi. Rett Sendromu tanısı konulan hasta yakın klinik izleme alındı. Takiplerinde nöbeti olmadı. Fizik tedavi re- 
habilitasyon, çocuk kardiyoloji ve çocuk psikiyatri bölümlerine yönlendirildi. Aileye genetik danışmanlık verildi.

\section{Olgu 2}

8 yaşında kız hasta dış merkezde nöromotor retardayon, hipoksik iskemik ensefalopati tanıları ile izlemdeyken ateşin eşlik ettiği 5 dakika süren jeneralize tonik klonik nöbet geçirme şikayeti ile servisimize yatırıldı. Hastanın prenatal ve postnatal öyküsünde özellik olmadığı, natal öyküde 4200 gr, 37 haftalık, normal spontan vaginal yol ile zorlu bir doğum geçirdiği öğrenildi. 9 ayına kadar normal motor gelişim basamaklarına sahipken, 10. aydan sonra regresyon belirtildi. Anne ve babanın 1. derece akraba olduğu (amca çocukları), ablada 17 yaşında mental ve motor gerilik başladığı belirtildi. Fizik muayanesinde genel durumu orta, baş çevresi $43.5 \mathrm{~cm}$ (<- $2 \mathrm{SD}$ ), kaba yüz görünümü, yüksek damak, streotipik el hareketleri vardı, derin tendon refleksleri canlı, tonus artmış, diğer sistem muayaneleri doğaldı. Rutin hemogram, biokimya, metabolik tetkikleri (idrar kan aminoasitleri, idrar organik asitleri, tandem kütle spektrometresi (tandem MS ) aminoasit ve açilkarnitin normaldi. Çekilen EEG'de dizorganize zemin ritmi ile birlikte multifokal dominans jeneralize ve bisenkron diken/diken dalga deşarjlarının zaman zaman zemin ritmini yavaşlattığ 1 izlendi (Resim 3).

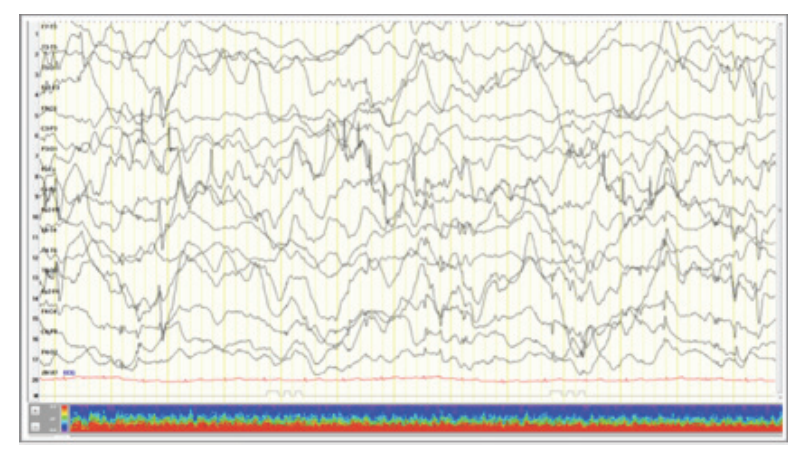

Resim 3. Elektroensefalografide dizorganize zemin ritmi ile birlikte multifokal dominans jeneralize ve bisenkron diken/ diken dalga deşarjları
Kranial magnetik rezonans görüntülemesi normal olarak değerlendirildi. Rett Sendromu ön tanısı ile genetik bölümü ile konsulte edilen hastanın yapılan genetik analizinde MECP2 geninde heterozigot C.808T C >T (p.Arg270Ter) mutasyonu saptanıldı. Rett Sendromu tanısı konulan hastaya valproik asit başlandı ve yakın klinik izlemde nöbetleri olmadı. Aileye genetik danışmanlık verildi. Hastamız çocuk psikiyatri, çocuk kardiyoloji ve fizik tedavi polikliniğine yönlendirildi.

\section{Tartıșma}

Rett Sendromu kendine özgü gidişi sayesinde tanısı klinik olarak konulur ve genetik tanı ile kesinleştirilir. Klasik RS doğum öncesi, doğum sırası, doğum sonrası dönemde ilk altı ayda gelişmenin normal olması, doğumda baş çevresinin normalken beş ay-dört yaş arasında mikrosefali gelişmesi, edinilmiş amaca yönelik el becerilerinin kaybı (6-30 aylar arasında), alıcı ve ifade edici dilde ağır bozulma, ciddi psikomotor gerilik, stereotipik el hareketleri (burma, sıkma, ağıza götürme), apraksi, ataksi tanı için gerekli kriterlerdir. ${ }^{3}$ Hiperventilasyon, nefes tutma epizodları, elektroensefalografi (EEG) anormallikleri, nöbetler, spastisite, bruksizm, uyku bozuklukları, periferik vazomotor sorunlar, skolyoz varlığı tanıyı destekler. ${ }^{4}$

Özellikle orta hatta yapılan el çırpma, ovalama, ovuşturma, yıkama, vurma, elleri ağıza götürme, parmaklarını bükme ve sıkma şeklinde stereotipik el hareketleri hastalığın karakteristik özelliklerindendir. İki hastamızda da bizi tanıya gösteren bulgular; sterotipik el hareketleri, mikrosefali; psikomotor regresyondu.

Epileptik nöbetler literatürde Rett Sendromlu hastalarda \%60-94 gibi farklı sıklıklarda bildirilmiştir. ${ }^{5}$ Nöbetler genellikle iki yaşından sonra başlamaktadır ve prevalans yaşla artmaktadır. En sık görülen nöbet tipi; jeneralize tonik klonik nöbetlerdir. Bizim iki hastamızda da jeneralize tonik klonik vasıfta nöbetler görüldü. Epileptik nöbetler hastalarda sıklıkla görülen stereotipik hareketlerle karı- 
şabilir ve tanınamayabilir, bu nedenle epileptik olmayan davranışsal hareketlerden ayrımında elektroensefalografi (EEG) önemli bir araçtır. ${ }^{6}$ Ancak literatürde EEG bulguları konusunda çok az bilgiye ulaşılabilmektedir. Epileptik nöbetlerin tedavisinde çeşitli antikonvülzanlar kullanılır. İki olgumuzda da çekilen EEG' de epileptik aktivite saptandı; ilk olguda doz ayarlanması yapıldı, ikinci olguda valproik asit $20 \mathrm{mg} / \mathrm{kg}$ 'dan 2 dozda kademeli olarak başlandı. Yakın klinik izlemlerinde hastaların nöbetleri olmadı.

Rett Sendromu patogenezinde MECP2 genindeki mutasyonlar yer alır. Xq28 bölgesinde yer alan MECP2 geni metil-CpG bağlayıcı proteini (MeCP2) kodlar. MeCP2 proteini vücutta birçok yerde bulunmasına rağmen, özellikle beyinde çok miktarda bulunur. MECP2 geninde meydana gelen inaktivasyon mutasyonları ekspresyonu gerekmeyen genlerin uygunsuz ve fazla ekspresyonu ile sonuçlanır ve bu durum santral sinir sistemi olgunlaşması üzerine olumsuz etkilere yol açar. ${ }^{7}$

MECP2 mutasyonlar1 klasik Rett Sendromunda \%95 oranında saptanır. Biz de bu çalışma ile klinik olarak düşündüğümüz ön tanıyı genetik analiz ile kesinleştirmiş olduk. Rett Sendromunda mental-motor geriliğin yeni başladığı dönemde yada gerilik öyküsünün net alınamadığı hastalarda tanı gecikebilir. Hastalarda doğuştan metabolik hastalıklar, hipoksi, iskemi yada travmaya bağlı beyin zedelenmesi olmadığı gösterilmelidir. İkinci olgumuzda dış merkezde hipoksik iskemik ensefalopati tanıları ile izlemde olduğu; öykü derinleştirildiğinde normal spontan vaginal yol ile zorlu bir doğum öyküsünün olduğu, doğduktan sonra ağladığg, yenidoğan yoğun bakımda yatış öyküsünün olmadığı öğrenildi. Ayrıca Rett Sendromu epileptik sendromlar, metabolik hastalıklar, mitokondriyal hastalıklar, lizozomal depo hastalıkları, serebral palsi, Angelman Sendromu, otizm gibi hastalıklarla karışabilmektedir. ${ }^{8}$

Sonuç olarak Rett Sendromu tanısı detaylı öykü, fizik muayane bulguları ve hastalığın kendine özgü bulguları ile klinik olarak şüphelenilerek genetik analiz ile kesinleşti- rilir. Bazen bu Sendrom tanı karmaşasına yol açmaktadır. İlk 6 aya kadar normal mental motor gelişimi olan, 6 aydan sonra başlayan mikrosefali, mental motor retardasyon, sterotipik el hareketleri, alıcı ve ifade edici dilde gerilik, göz temasının olmaması ve nöbetleri olan hastada Rett Sendromundan şüphelenilmelidir.

\section{Çalışma maddi olarak desteklenmemiştir.}


Sakarya Tip Dergisi 2010;10(1):128-132

\section{Kaynaklar}

1. Neul JL, Kaufmann WE, Glaze DG, et al. Rett syndrome: revised diagnostic criteria and nomenclature. Ann Neurol 2010;68:944-950

2. Bienvenu T, Philippe C, De Roux N, et al. The incidence of Rett Syndrome in France. Pediatr Neurol 2006;34: 372-375

3. Diagnostic criteria for Rett syndrome. The Rett Syndrome Diagnostic Criteria Work Group. Ann Neurol 1988;23(4):425-8

4. Hagberg B, Hanefeld F, Percy A, Skjeldal O. An update on clinically applicable diagnostic criteria in Rett syndrome. Comments to Rett Syndrome Clinical Criteria Consensus Panel Satellite to European Paediatric Neurology Society Meeting, Baden Baden, Germany, 11 September 2001. Eur J Paediatr Neurol 2002;6(5):293-7
5. Nissenkorn A, Gak E, Vecsler M, Reznik H, Menascu S, Ben Zeev B. Epilepsy in Rett Syndrome-the experience of a National Rett Center. Epilepsia 2010;51(7):1252-8

6. d'Orsi G, Trivisano M, Luisi C, Demaio V, Di Claudio MT, Pascarella MG, et al. Epileptic seizures, movement disorders, and breathing disturbances in Rett Syndrome: diagnostic relevance of video-polygraphy. Epilepsy Behav 2012;25(3):401-7

7. Cuddapah VA, Pillai RB, Shekar KV, et al. Methyl-CPG-binding protein 2 (MECP2) mutation type is associated with disease severity in Rett Syndrome. J Med Genet 2014;51:52-158

8. Ellaway C, Christodoulou J. Rett Syndrome: clinical update and review of recent genetic advances. J Paediatr Child Health 1999;35:419-426 